Research article

urn:1sid:zoobank.org:pub:BA6707B1-9DAD-4448-9431-47B7E9B63980

\title{
Redescription of Tapinesthis inermis (Araneae, Oonopidae), with detailed information on its ultrastructure
}

\author{
Arnaud HENRARD ${ }^{1,2,5,{ }^{*}, \text { Rudy JOCQUÉ }}{ }^{1,6} \&$ Barbara C. BAEHR ${ }^{3,4,7}$ \\ ${ }^{1}$ Section Invertebrates non-insects, Royal Museum for Central Africa, \\ Leuvense Steenweg 13, B-3080 Tervuren, Belgium \\ ${ }^{*}$ Corresponding author. E-mail: arnaud.henrard@gmail.com \\ ${ }^{2}$ Earth and Life Instititute, Biodiversity Research Center, Université Catholique de Louvain, \\ Place Croix du Sud 1-4, B-1348 Louvain la Neuve, Belgium \\ ${ }^{3}$ Queensland Museum, PO Box 3300, South Brisbane, QLD 4101, Australia \\ ${ }^{4}$ CSER, School of Environmental and Life Sciences, University of Newcastle, \\ Callaghan, NSW 2308, Australia \\ ${ }^{5}$ urn:1sid:zoobank.org:author:E1B02E6E-D91C-43FE-8D8C-CD102EFEE3B4 \\ ${ }^{6}$ urn:lsid:zoobank.org:author:CF15016C-8CD1-4C9D-9021-44CA7DC7A5D5 \\ ${ }^{7}$ urn:Isid:zoobank.org:author:CFAFC574-5691-4A77-AF0C-E6B8B0563340
}

\begin{abstract}
Tapinesthis inermis Simon, 1882, the only species in the genus, is widely distributed in western Europe. This redescription provides the first information on the ultrastructure of the species using SEM. The morphology of the spinnerets, tarsal claws and tarsal organs, and the internal structure of the female genitalia and the male palp are described and illustrated in detail. The combination of these structures is very similar to those encountered in some dysderoid spiders and supports the basal placement of Tapinesthis among Oonopinae. The phylogenetic relationships of the species are discussed. The only female among the three syntypes is designated as the lectotype.
\end{abstract}

Key words. Female genitalia, male palp, organ receptors, spinnerets, systematics

Henrard A., Jocqué R. \& Baehr B. 2014. Redescription of Tapinesthis inermis (Araneae, Oonopidae) with detailed information on its ultrastructure. European Journal of Taxonomy 82: 1-20. http://dx.doi.org/10.5852/ejt.2014.82

\section{Introduction}

The spider genus Tapinesthis Simon, 1914 is monospecific, containing the single species T. inermis (Simon, 1882), widely distributed in Europe (Le Peru 2011; Platnick 2013). This rare species is often found in houses or in the neighbourhood of habitations (Kraus 1967; Heimer \& Nentwig 1991; Lazarov et al. 2001; Korenko et al. 2007; Van Keer et al. 2006). Tapinesthis inermis thus appears to be strongly synanthropic, as it is often found in urban areas. Saaristo \& Marusik (2009) even employed the term "hemisynanthropic" to describe its habitat preference. However, it has also been collected in natural habitats such as forests (Dalmas 1920; Le Peru 2007), garrigues and dry grasslands (Le Peru 2011) or near cliffs with a dense cover of ivy (e.g., Rochers de Marches les Dames in Belgium, this study). In Belgium, T. inermis appears to be abundant in litter and among ivy (Van Keer et al. 2006; pers. obs.). 
The species is often found together with Oonops domesticus and O. pulcher (Van Keer et al. 2006, 2010), and, at least in Belgium, also with Harpactea hombergi (Scopoli, 1763) (pers. obs.).

Tapinesthis inermis is easy to identify and has been reviewed by many authors (see Platnick 2013). Originally, the species was described as Oonops inermis and only the female was known (Simon 1882). Later, Simon (1914) created the genus Tapinesthis for this species and described both sexes.

A remarkable redescription of both males and females was provided by Kraus (1967), with detailed drawings of the genitalia and other body parts. Other significant illustrations and photos have been published by Korenko et al. (2007) (female prosoma, vulva) and by Saaristo \& Marusik (2009) (male and female habitus, male palp, female genitalia). However, this is the first detailed morphological study of $T$. inermis using SEM images, providing detailed information about the ultrastructure of the female genitalia, the spinnerets, mouthparts and legs. We also compare the genitalia with those of related taxa and discuss the relationships of this species with other oonopids.

The results of this work have previously been used for the polarization of characters in a phylogenetic study of Afrotropical Orchestina Simon, 1882 (Henrard \& Jocqué 2012). However, one particular character, the number of tarsal organ receptors, is updated here and the consequences are dealt with in the discussion.

\section{Material and methods}

Specimens were observed with a Zeiss Stemi 2000 stereo microscope. Measurements and photographs of the habitus and details of the mouthparts and detached male palps and genitalia were taken with a Leica MZ16 using the LAS automontage software (ver. 3.8). Female genitalia were dissected, digested with pancreatin and then immersed in $75 \%$ ethanol. One male palp was detached and temporarily mounted in a clearing mixture of methyl salicylate and cedukol (Merck, Darmstadt), observed with a Leitz Dialux 22 microscope and subjected to automontage with the Syncroscopy software (ver. 5.03.61). For SEM photos, specimens were dried in HMDS (36 h), gold coated, and examined and photographed with a JEOL 6480 LV scanning electron microscope. All measurements are in millimetres.

This paper follows the terminology of Burger's series of papers (Burger 2009, 2011a, 2011b, 2013; Burger \& Michalik 2010) with a few adaptations.

The following abbreviations are used:

$\begin{array}{ll}\mathrm{ALS} & =\text { anterior lateral spinnerets } \\ \mathrm{ALE} & =\text { anterior lateral eyes } \\ \mathrm{ARe} & =\text { anterior receptaculum } \\ \mathrm{AS} & =\text { anterior sclerite } \\ \mathrm{D} & =\text { duct } \\ \mathrm{Ht} & =\text { holotype } \\ \mathrm{FA} & =\text { flattened apodeme } \\ \mathrm{MNHN} & =\text { Muséum national d'Histoire naturelle, Paris (C. Rollard) } \\ \mathrm{MRAC} & =\text { Musée Royal de l'Afrique Centrale, Tervuren (R. Jocqué) } \\ \mathrm{PBI} & =\text { Planetary Biodiversity Inventory project } \\ \mathrm{PER} & =\text { posterior eye row } \\ \mathrm{PLE} & =\text { posterior lateral eyes } \\ \mathrm{PLS} & =\text { posterior lateral spinnerets } \\ \mathrm{PME} & =\text { posterior median eyes } \\ \mathrm{PMS} & =\text { posterior median spinnerets } \\ \mathrm{Pp} & =\text { posterior plate }\end{array}$




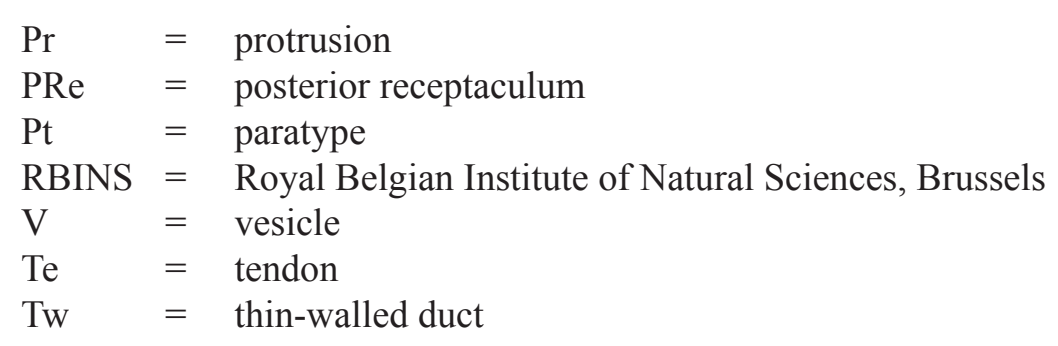

\title{
Results
}

\author{
Class Arachnida Cuvier, 1812 \\ Order Araneae Clerck, 1757 \\ Family Oonopidae Simon, 1890
}

Tapinesthis Simon, 1914

\section{Diagnosis}

Soft-bodied, pale Oonopidae with strongly sloping cephalothorax provided with dark net-shaped pattern, without leg spines, with unipectinate tarsal claws; pedicel with meshed texture; male palp with short sclerified sperm duct and female genitalia with wide median T-shaped structure visible by transparency, flanked by two rounded apodemes.

\section{Description}

\section{Male}

Cephalothorax. Carapace in vivo pale yellowish-orange (Fig. 1A-B) to pinkish, in ethanol yellowishwhite to pale orange (Figs 2A-B, 3A-D), with dark net-shaped pattern and dark margins; non-marginal pars cephalica setae present in three rows, ovoid in dorsal view, pars cephalica strongly sloping in lateral view, reaching highest point at level of second coxa (Fig. 2E), anteriorly narrowed to 0.49 times its maximum width or less, with rounded posterolateral corners (Fig. 2A-B), surface of elevated portion of pars cephalica smooth, sides smooth, with radiating patches of smooth platelets (Fig. 6A-B); thorax without depressions, fovea absent, lateral margin undulate, smooth; pars cephalica setae needle-like. Clypeus margin curved downwards in front view (Fig. 2G), sloping forward in lateral view (Fig. 2E), high, ALE separated from edge of carapace by their radius or more. Eyes (Fig. 2A, E): six, well developed, all subequal, ALE oval, PME circular, PLE circular; posterior eye row recurved from both above and front; ALE separated by their radius to diameter, ALE-PLE separated by less than ALE radius, PME touching, PLE-PME separated by less than PME radius, ALE-PME separated by less than PME radius. Sternum (Fig. 2C) yellowish white, with faint radiating dark stripes, longer than wide, with radial smooth furrows between coxae I-II, II-III and III-IV, anterior margin with semicircular depression on the middle half, posterior margin extending posteriorly beyond anterior edges of coxae IV as single extension, distance between coxae approximately equal; setae abundant, evenly scattered, without hair tufts. Mouthparts: chelicerae, endites and labium yellowish white. Chelicerae (Fig. 6F) straight; without teeth on both promargin and retromargin; fangs directed medially, paturon inner margin with scattered setae. Labium (Figs. 2C, 6C-D, F) rectangular, fused to sternum, anterior margin indented at middle, basal corners with small circular depression, sclerotization as in sternum; with 6 or more setae on anterior margin, subdistal portion with unmodified setae. Endites (Fig. 6C-G) distally not excavated, serrula present in single row, anteromedian tip unmodified, posteromedian part unmodified, sclerotization as in sternum; anterior margin with ventral row of spatulate setae and dorsal row of distally pectinate setae, median margin with finely barbed setae.

AвDomen (Fig. 2A-B, D-F). Ovoid, rounded posteriorly,without scuta; dorsum soft portions yellowbrown, without color pattern. Dorsum setae present, needle-like. Epigastric area setae uniform, needle- 
like. Postepigastric area setae present, needle-like. Pedicel with meshed texture (Fig. 6C) as in Orchestina (see Henrard \& Jocqué 2012, figs. 21, 113, 114, 404), abdomen extending anteriad of pedicel. Colulus present (Fig. 9A), with four setae. Spinnerets (Fig. 9B-D): ALS with one major ampullate gland spigot emerging from cylindrical tubercle and two piriform gland spigots emerging from shallow tubercle; PMS with one minor ampullate gland spigot emerging from cylindrical tubercle; PLS with two aciniform gland spigots emerging from cylindrical tubercle.

LEGS. White, without color pattern; femur IV not thickened, same size as femora I-III, patella plus tibia I longer than carapace, tibia I unmodified, metatarsi of at least leg II in the middle and IV at basal quarter, with eye-shaped smooth gland outlet with single pore (Fig. 12C-E). Leg spines absent. Tarsal claws (Fig. 10A-F) unipectinate, tarsal proclaws and retroclaws inner face smooth; tarsus I-IV superior claws with six teeth on lateral surface of proclaw, six teeth on lateral surface of retroclaw. Tarsi claw tuft with three carpeted setae. Tarsi I to IV without inferior claw. Trichobothria (Fig. 12D-E) with rounded bothrium, internal texture of aperture not grate-like, hood covered by numerous low, closely spaced ridges; sometimes accompanied by eye shaped structure with unknown function (Fig. 12C-D). Tarsal organ (Fig. 11A-D, H-I) pear-shaped, margin raised above surroundings, with 4 receptors on legs I and II, with 3 receptors on legs III and IV. In a probably unusual case, the tarsal organ has only 1 receptor on both legs IV (Fig. 11H-I), whereas I-III of the same specimen have the usual 4-4-3 formula (not illustrated). According to observations made on other oonopids the formula appears to be 3-3-2-2, since the distalmost receptor is distally bifid, but both parts stem from a common base as in Stenoonops Simon, 1891 (Platnick \& Dupérré 2010).

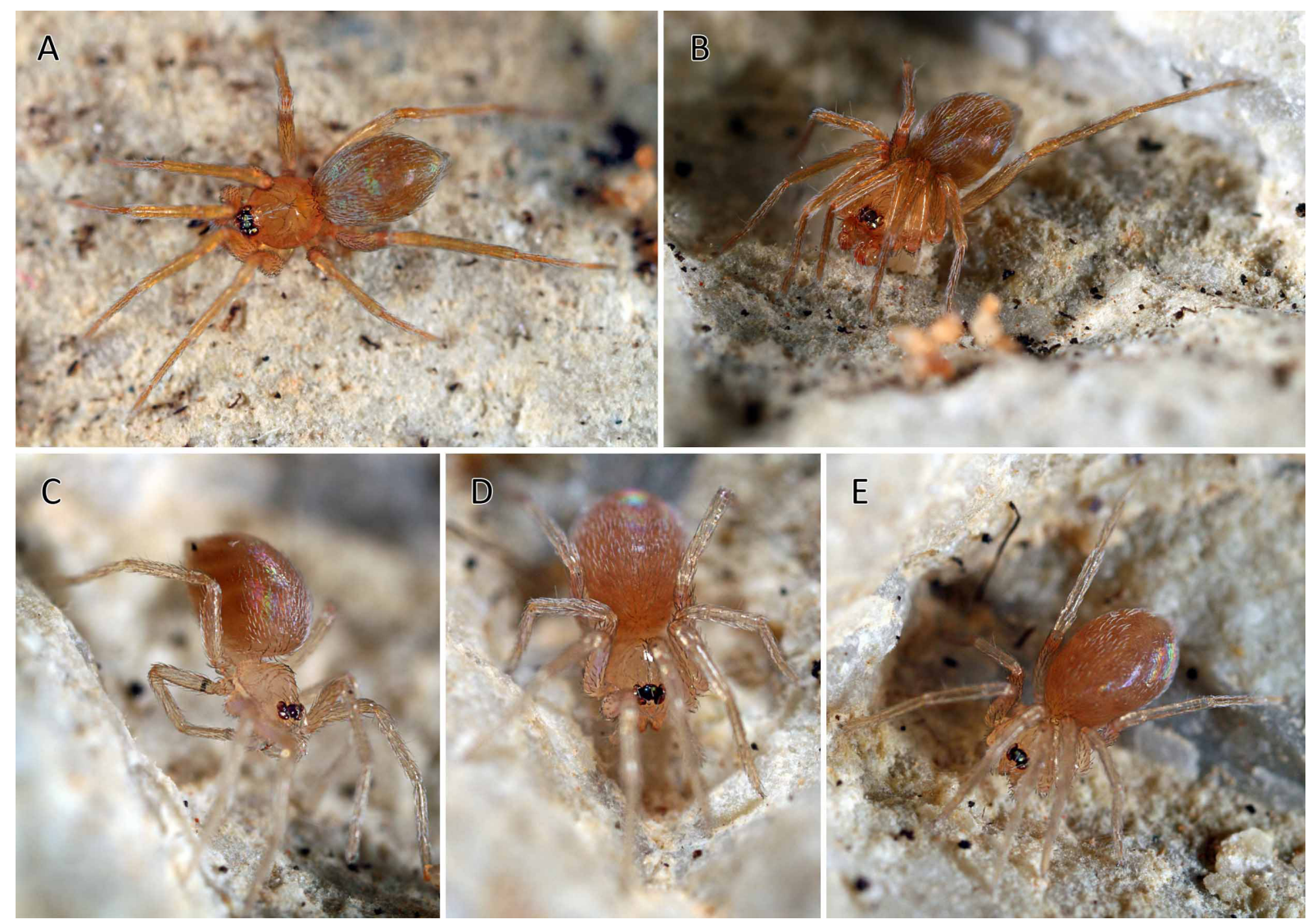

Fig. 1. Tapinesthis inermis photographed in vivo. A. § (PBI 33564). B. Same. C. $q$ (PBI 33267). D. Same. E. Same. Remark color differences of cephalothorax between $\delta$ and $q$. For explanation, see text. 

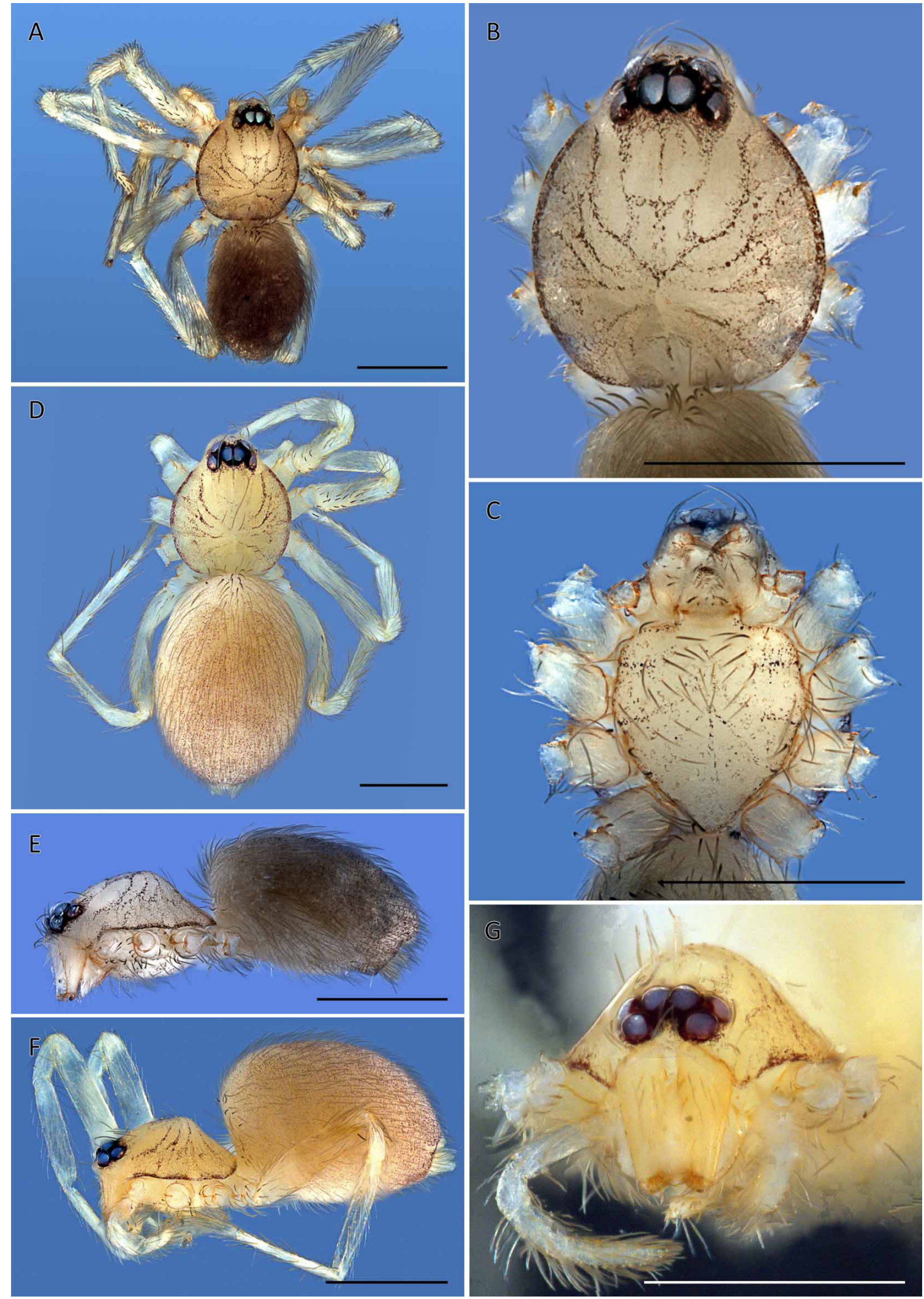

Fig. 2. Tapinesthis inermis. A. đ(PBI 33564), habitus, dorsal view. B. Same, carapace. C. Same, sternum, ventral view. D. ㅇ (PBI 33267), habitus, dorsal view. E. $\widehat{\jmath}$ (PBI 33564), habitus, lateral view. F. Same, $q$ (PBI 33267). G. + (PBI 08123), carapace, anterior view. Scale bars $=0.5 \mathrm{~mm}$. 
Genitalia (Figs. 4A-E, 7A-D). Epigastric region with sperm pore small, narrow, slit-like, situated at level of anterior spiracles. Palp normal size, not strongly sclerotized, right and left palps symmetrical, proximal segments white; trochanter normal size, unmodified; femur normal size, two or more times as long as trochanter, without posteriorly rounded lateral dilation, attaching to patella basally; patella shorter than femur, not enlarged, without prolateral row of ridges, setae unmodified; tibia ventral margin swollen; cymbium white, ovoid in dorsal view, not fused with bulb, not extending beyond distal tip of bulb, plumose setae absent, without stout setae, without distal patch of setae; bulb white, 1 to 1.5 times as wide as cymbium, stout, piriform with frontal margin slightly concave, tapering apically with long, medially bent embolus, distal sclerotized part of seminal duct (D) short, restricted to distal part, abruptly interrupted, internally with poorly defined vesicle (V), opening into embolus through duct with basal part thin-walled (Tw), distal part sclerotized; tendon (Te) running from base of cymbium to distal end of vesicle $(\mathrm{V})$; embolus simple, dark, tube-shaped, flattened apically, tip blunt, grooved, appearing pale.

Female (Figs 1C-E, 2D, F-G)

As male except as noted.

Cephalothorax. Female palpal claw absent; spines absent. Tarsal organs (Fig. 11A-D) as in male.

A

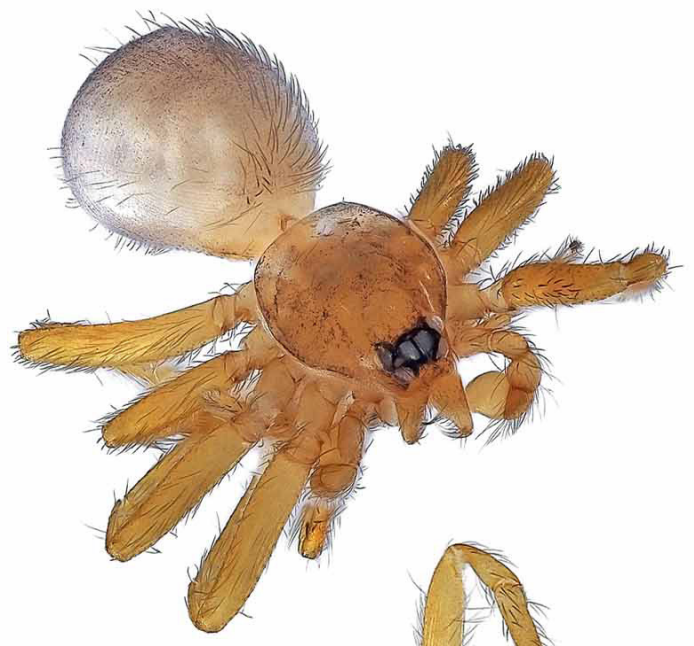

C

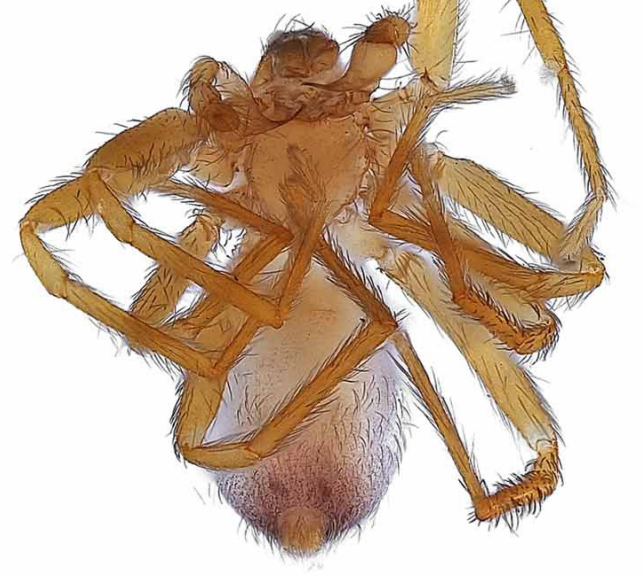

B
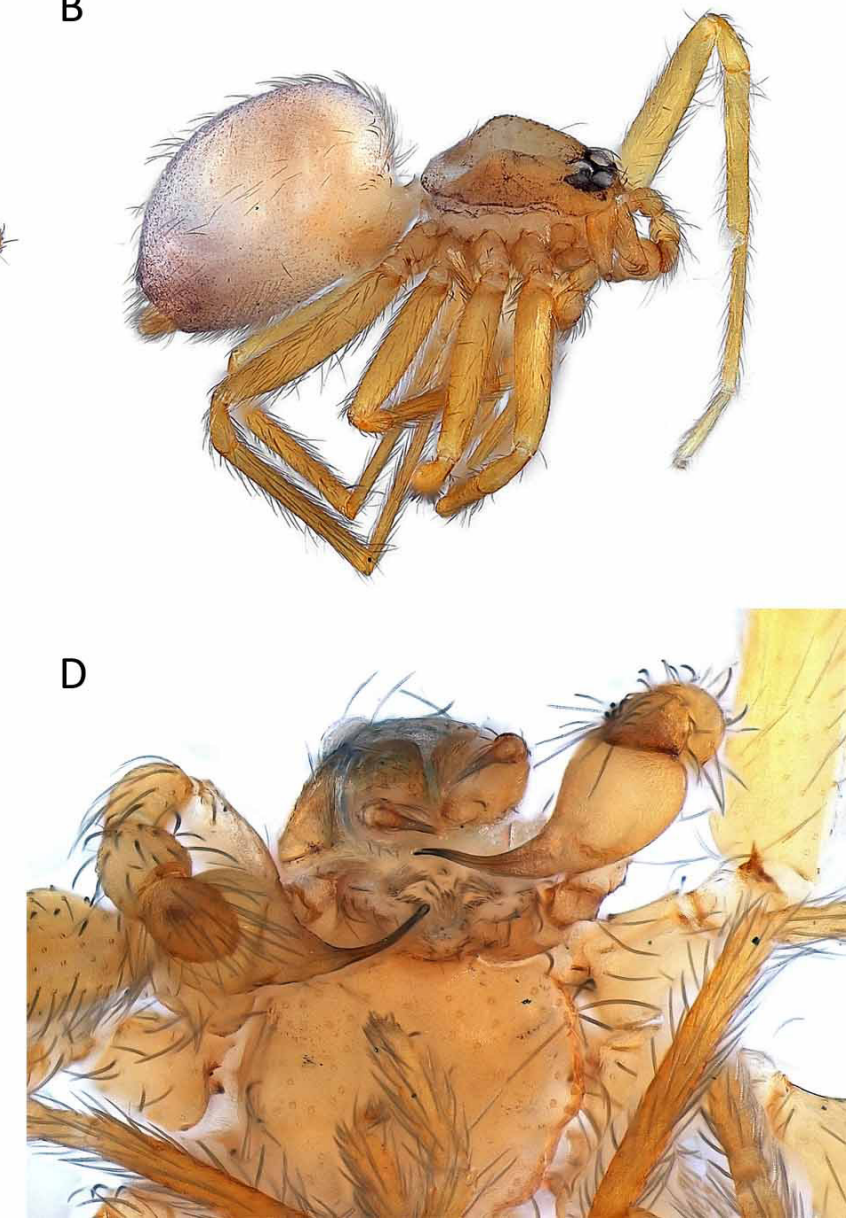

Fig. 3. Tapinesthis inermis, ô from the Czech Republic (PBI 32902). A. Habitus, dorsal view. B. Same, lateral view. C. Same, lateral view. D. Prosoma, ventral view. 
ABDOMEN. Spinnerets (Fig. 9E-H): ALS with one major ampullate gland spigot emerging from cylindrical tubercle and three piriform gland spigots emerging from shallow tubercle; PMS with minor ampullate gland spigot and three aciniform gland spigots; PLS with six aciniform gland spigots.

Genitalia (Figs 5A-D, 8A-G). Shape: anterior epigastric margin strongly sclerotized, preceded by T-shaped structure visible in transparency (AS), with larger, square part (ARe) in between, the latter provided at base with fine transverse sclerite (T) ending in two faint procurved lobes (FA) extending as far as lateral protrusions (Pr) of frontal T-shape (AS). SEM view, details: anterior sclerite (AS) short, T-shaped, with lateral protrusions $(\mathrm{Pr})$ well developed and provided with ramified ridges on anterior side and dorsally near extremities; AS connected with anterior receptaculum (ARe) antero-ventrally; ARe about half as wide as AS including Pr, square, provided dorsally and apically with rows of gland ducts (GD) confined in frontal groove; ARe adjacent to transverse sclerite (T) ending laterally in well developed,
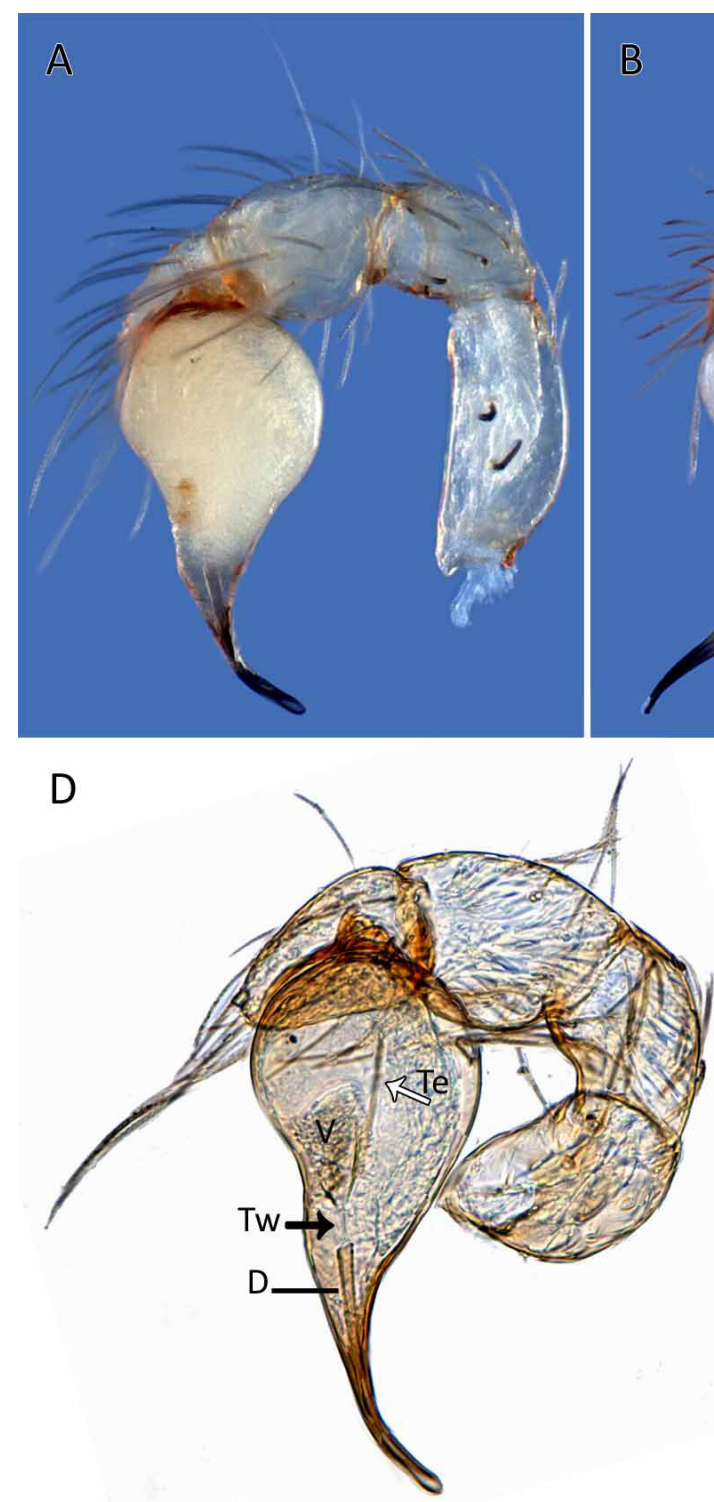
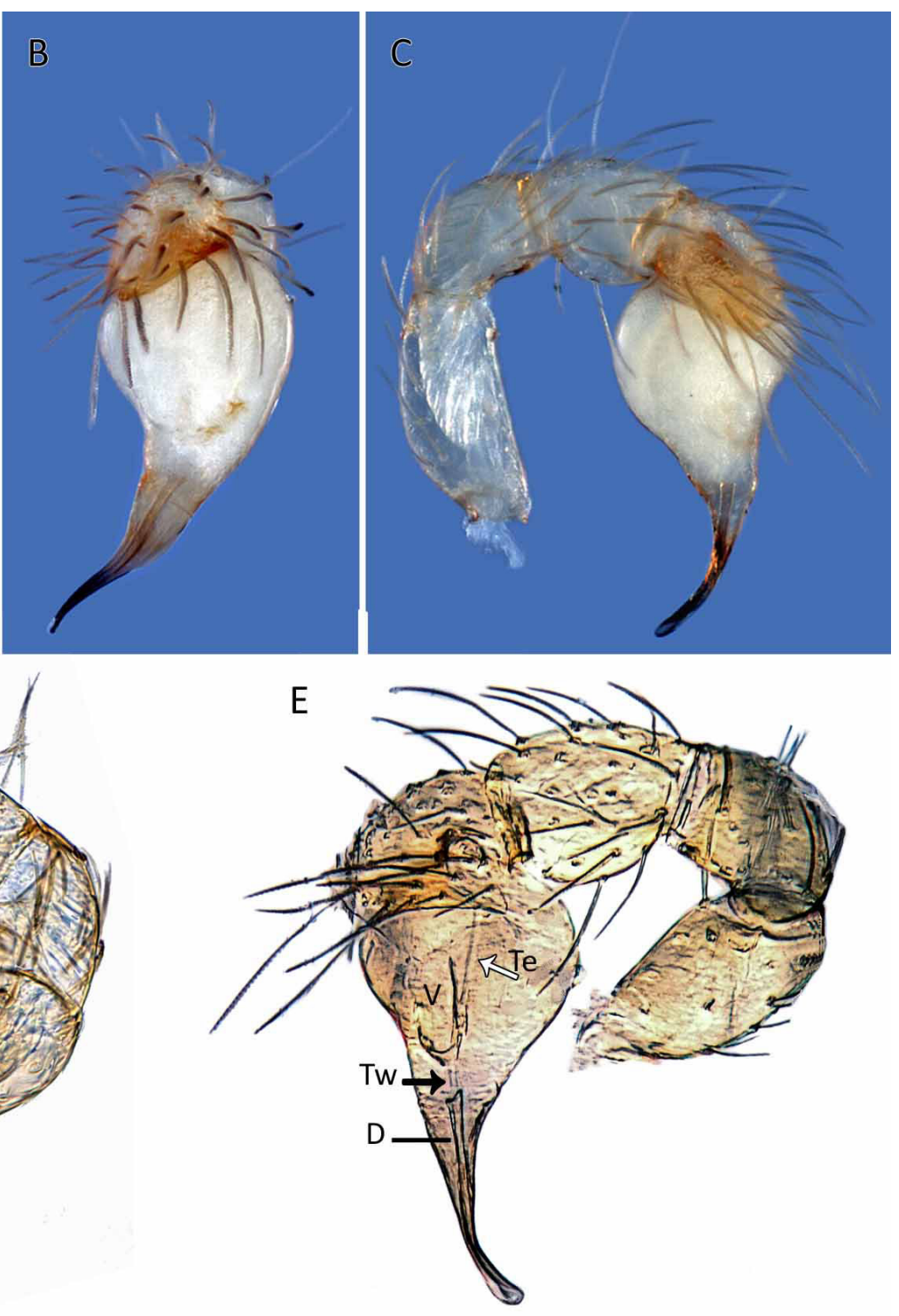

Fig. 4. Tapinesthis inermis. - A-C. $\widehat{\partial}$ (PBI 33564), palp. A. Retrolateral view. B. Same, frontal view. C. Same, prolateral view. - D. ठ̊ (PBI 09021), palp, prolateral view, transmitted light. - E. ठ palp, lateral view after Saaristo \& Marusik, 2009 (modified). - D: duct; Te: tendon; Tw: thin-walled duct; V: vesicle. 
bilobed, flattened apodeme (FA), its dorsal extremity anchoring into the posterior receptaculum (PRe); PRe well developed, egg-shaped, emerging from base of ARe. Uterus externus not visible.

\section{Tapinesthis inermis (Simon, 1882)}

Oonops inermis Simon, 1882: 240.

Tapinesthis inermis. - Simon 1914: 88, 90. — Kaston 1948: 61, figs 4-6. — Kraus 1967: 382, figs 1-10. — Heimer \& Nentwig 1991: 52, fig. 110. — Lazarov, Deltshev \& Blagoev 2001: 8, figs 5-6. — Trotta 2005: 170, figs 369-370. — Van Keer 2006: 36, fig. 3. — Korenko, Rezác \& Pekár 2007: 6, figs 1-3. Saaristo \& Marusik 2009: 64, figs 11-14, 23, 27. — Le Peru 2011: 307, fig. 537.
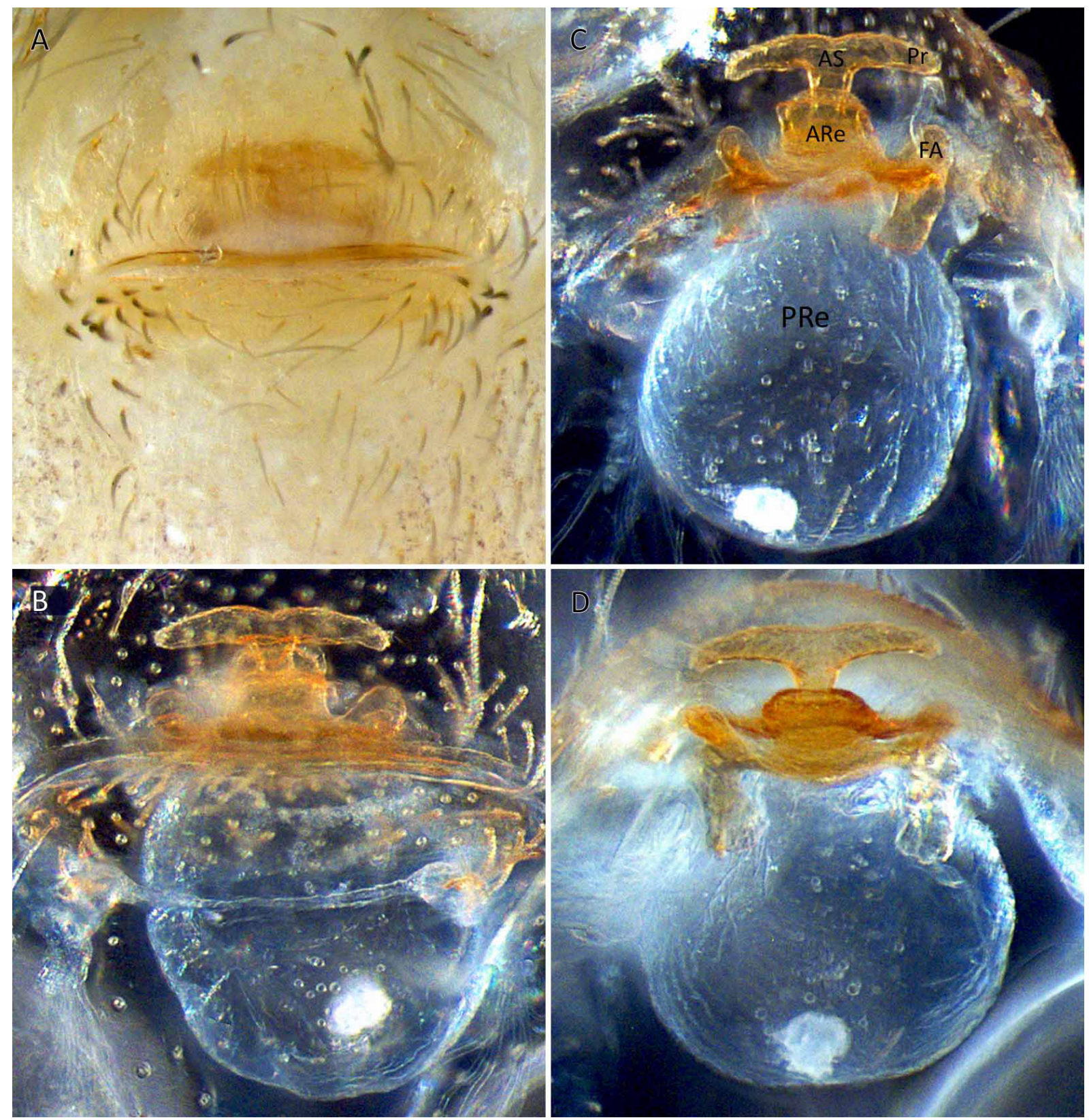

Fig. 5. Tapinesthis inermis, genitalia of $q$ (PBI 33267) A. Genital area, ventral view. B. Same, after digestion, ventral view. C. Same, dorsal view. D. Same, anterior view. - ARe: Anterior Receptaculum; AS: Anterior Sclerite; FA: Flattened Apodeme; Pr: lateral Protrusion; PRe: Posterior Receptaculum. 


\section{Material examined}

Lectotype (here designated)

+, Oonops inermis E.S. [= E. Simon], Gall. m. [= Gallia mediterranea?], MNHN AR1468 pars (PBI OON 6262 pars).

\section{Paralectotypes}

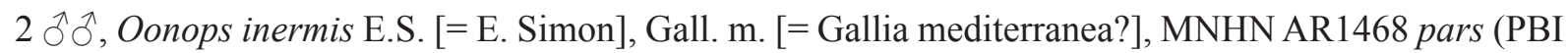
OON 6262 pars, PBI OON 6263).
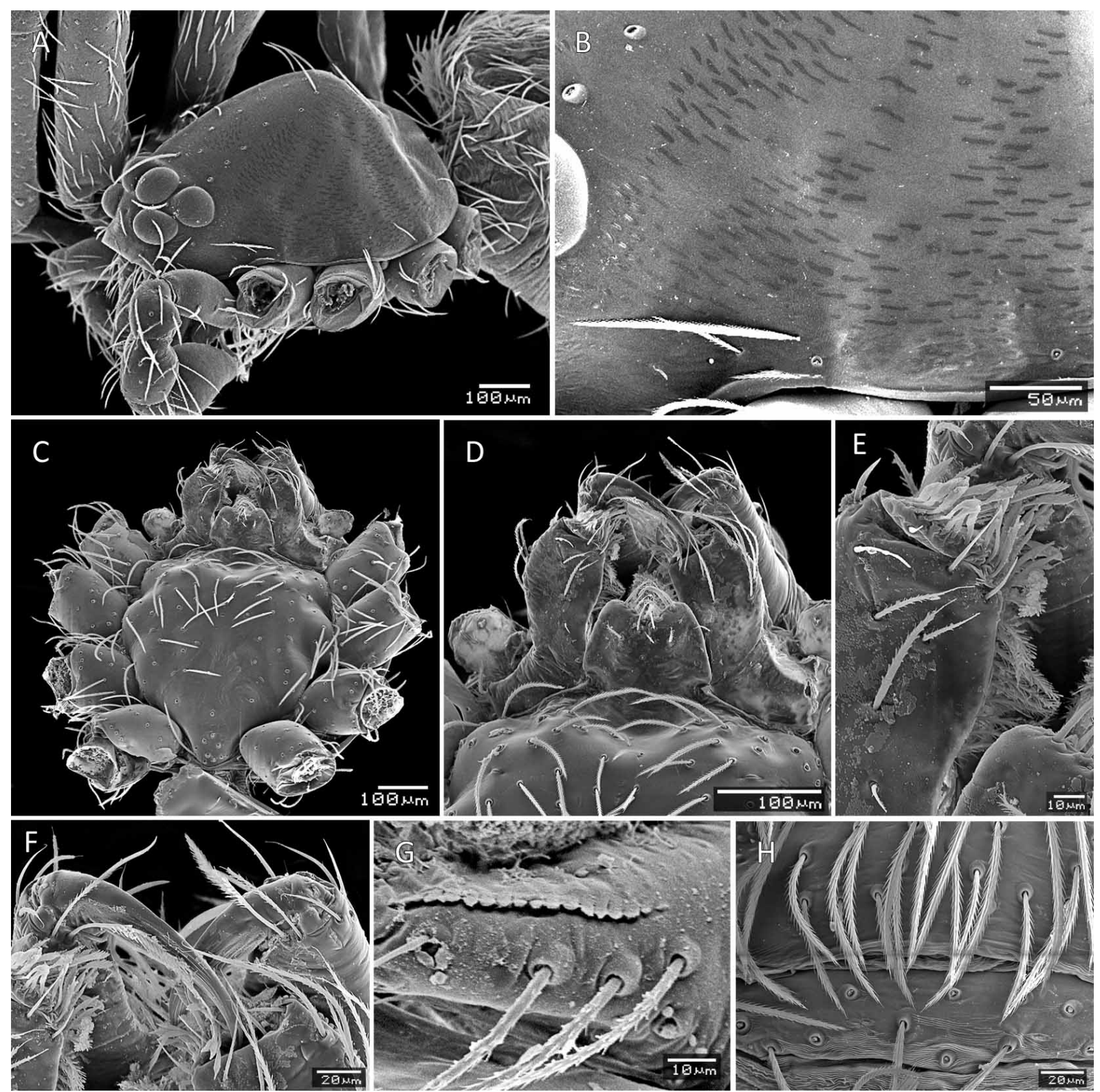

Fig. 6. Tapinesthis inermis, SEM views. A. đ (PBI 08123), carapace, antero-lateral view. B. Same, close up on the distribution of the smooth platelets. C. Oे (PBI 33564), sternum, ventral view. D. Same, mouthparts. E. Same, close up of endite setae. F. Same, cheliceral fangs. G. Ô (PBI 08123), endites, anterior view with detail of serrula. H. $\widehat{\partial}$ (PBI 33564), genital region, ventral view. 


\section{Other material}

BELGIUM: Antwerpen, Turnhout, forest remnant, under liana, $27 \mathrm{~m}, 51.31666^{\circ} \mathrm{N}, 4.93333^{\circ} \mathrm{E}, 19$ Oct. 2006, H. De Coninck, 5 $\jmath^{\jmath}$, RBINS I.G.32708 pars (PBI OON 8123 pars), 3 우우, RBINS I.G.32708 pars (PBI OON 8123 pars). Namur, Marche-les-Dames, 50.48250 ${ }^{\circ} \mathrm{N}, 4.94917^{\circ} \mathrm{E}, 25$ May 2010, A. Henrard, 1 , RBINS I.G.32708 pars (PBI OON 33267); Marche-les-Dames, understory, litter among ivy, $50.48250^{\circ} \mathrm{N}, 4.94917^{\circ} \mathrm{E}, 7$ Aug. 2011, A. Henrard, 1 今े, RBINS I.G.32708 pars (PBI OON 33564).

CZECH REPUBLIC: Zlínský Kraj, Lhota u Vsetina, Lhotské Paseky Sklep, building, $545 \mathrm{~m}$, 49.324528 ${ }^{\circ} \mathrm{N}, 17.936269^{\circ}$ E, 8 Aug. 2010, coll. Andrěj Mácháč, det. Jørgen Lissner, 1 đ (leg. J. Lissner, collection (V), 6821) (PBI OON 32902).

\section{Description}

\section{Male (PBI OON 33564)}

As for the genus except as noted. Total length 2.02 .

\section{Female (PBI OON 6262)}

As male except as noted. Total length 2.21.

\section{Distribution}

Austria, Belgium, Bulgaria, Czech Republic, France, Germany, Italy, Netherlands, Spain, Switzerland (after Le Peru 2011, extended).

\section{Remarks}

It was the count de Dalmas (1916), and then Kaston (1948), who pointed out that the specimen mentioned in Emerton's note on the New England spiders (Emerton 1909) was not Orchestina saltitans but Tapinesthis inermis. This single specimen is the only one ever recorded from the United States and was found in the cellar of the Boston Society of Natural History building, probably hidden in a package shipped from Europe to the Society (Kaston 1948). The mention 'introduced in USA' is therefore not valid as no further specimens were found, which indicates that no viable population of this species persists in the USA.
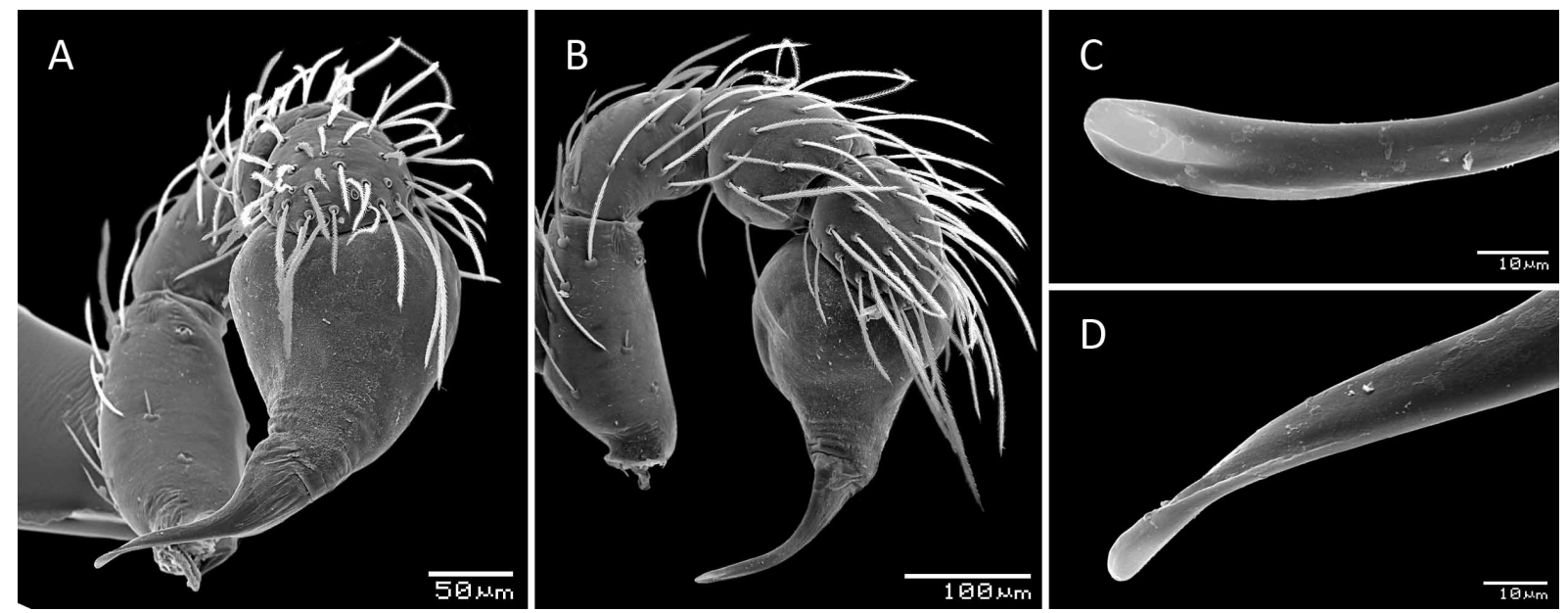

Fig. 7. Tapinesthis inermis, SEM views of $\partial$ (PBI 33564). A. Palp, frontal view. B. Same, prolateral view. C. Tip of embolus, ventral view. D. Same, retrolateral view. 

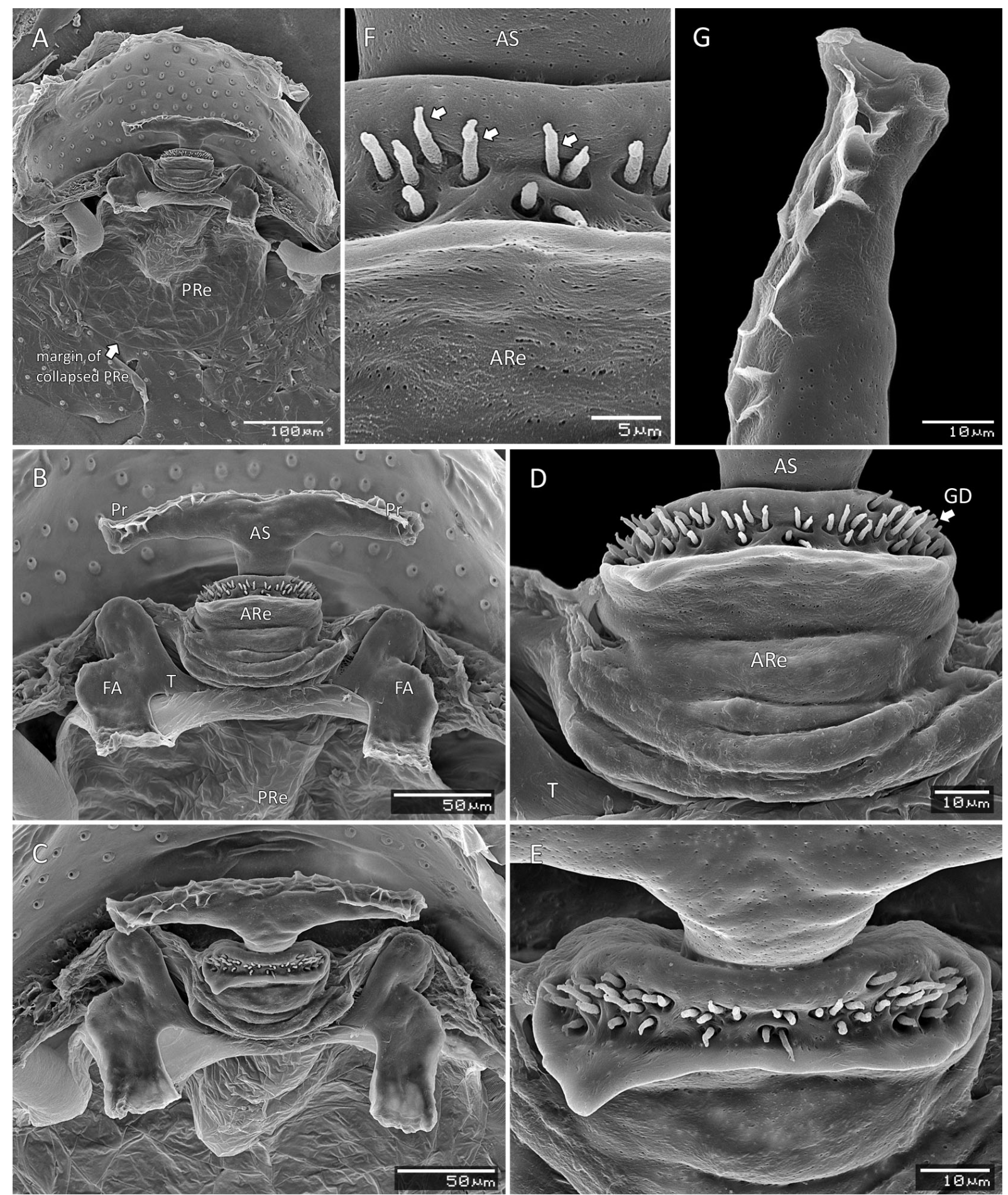

Fig. 8. Tapinesthis inermis, SEM views of $q$ genitalia (PBI 33267). A. Overview of genital area, dorsal view. B. Same, close up. C. Same, view slightly anterior. D. Anterior receptaculum (ARe), close up, arrow indicates gland ducts (GD). E. Same, anterior view. F. Same, detail of gland ducts (arrows). G. Lateral protrusion (Pr), detail, dorsal view. - ARe: Anterior Receptaculum; AS: Anterior Sclerite; FA: Flattened Apodeme; GD: Gland Duct; Pr: lateral Protrusion; PRe: Posterior Receptaculum; T: transverse sclerite. 


\section{Discussion}

Tapinesthis inermis is perhaps one of the easiest oonopid species to identify. This spineless "molles" oonopid, without abdominal scuta, can easily be recognized by the absence of ventral spines on the first tibiae, the net-shaped pattern on the carapace, the clumped eyes with slightly recurved PER and by the plesiomorphic aspect of the male palp and the female genital organs. Although this species is not easily seen, it cannot be considered as "rare". However, in the Czech Republic for instance, it is rarely found and only females were caught before this study (J. Král, pers. comm.; see also Korenko et al. 2007).

Dalmas (1916) mentions the occurrence of two adult seasonal forms, one in spring and one in summer, differing by the colouration and the hair cover. This observation is of interest since it is the only spider

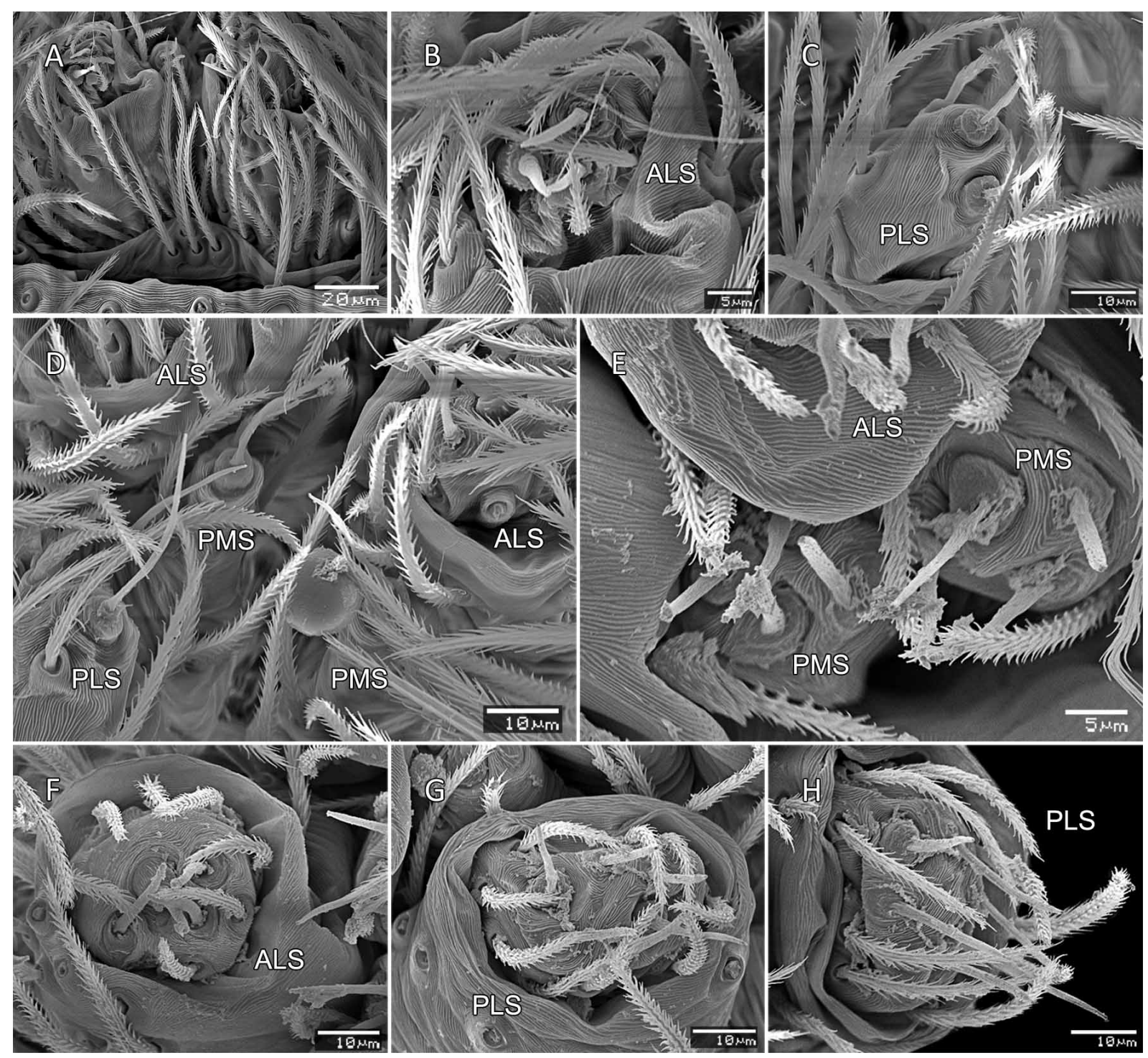

Fig. 9. Tapinesthis inermis, SEM views of spinneret area of $\delta$ (PBI 33564) and $q$ (PBI 33267). A. $\widehat{o}$, colulus, ventral view. B. Same, anterior lateral spinnerets, ventral view. C. Same, posterior lateral spinnerets. D. Same, focus on posterior median spinnerets. E. + , posterior median spinnerets, ventral view. F. Same, anterior lateral spinnerets. G. Same, posterior lateral spinnerets. H. Same, lateral view. - ALS: anterior lateral spinnerets; PLS: posterior lateral spinnerets; PMS: posterior median spinnerets. 
species for which seasonal forms have been recognized. However, our observations do not point in the same direction. The illustrations of Fig. 1 clearly show the colour differences between a specimen caught in summer (Fig. 1A-B) and another one photographed in spring (Fig. 1C-E). The spring specimen (female) is pale, whereas the one from August (male) is orange. The hair cover is similar in both cases. Since we know that the differences do not depend on the sex, we assume that the two forms are simply specimens of different age: they become darker, possibly by incorporating pigment from their prey, and might in some cases loose part of the hair cover. Dalmas (1916) possibly observed dark specimens that were born in autumn and had passed the winter, which, in the Mediterranean area where he made his observations, might have been perfectly possible.

\section{Genitalia, male palp}

The male palp of $T$. inermis is an excellent example of the basic plesiomorphic structure of the haplogyne palp: a piriform bulbus with a simple tubular embolus, without appendage as found in some segestriids. The latter character is the main difference with Oonopinus angustatus Simon, 1882, another spineless species (Simon 1882; Saaristo \& Marusik 2009; Le Peru 2011).

A number of features of the male palp can only be seen when it is cleared. The seminal duct has apparently two parts: a short, well sclerotized part leading into the embolus and a thin-walled part connecting to the faintly delimited, vesicle-like reservoir. Next to the latter, a thin linear structure runs from the base of the bulb to the distal end of the sperm reservoir. This structure is also visible in Spinestis nikita Saaristo \& Marusik, 2009 and Megaoonops avrona Saaristo, 2007 (Saaristo \& Marusik 2009) and some other oonopids. Saaristo and Marusik (2009) regard the linear structure adjacent to the sperm reservoir as a sclerite, but Grismado \& Ramirez (2013) and Grismado et al. (in press) clearly showed that this is a tendon, which is in accordance with the findings of Huber (2004).
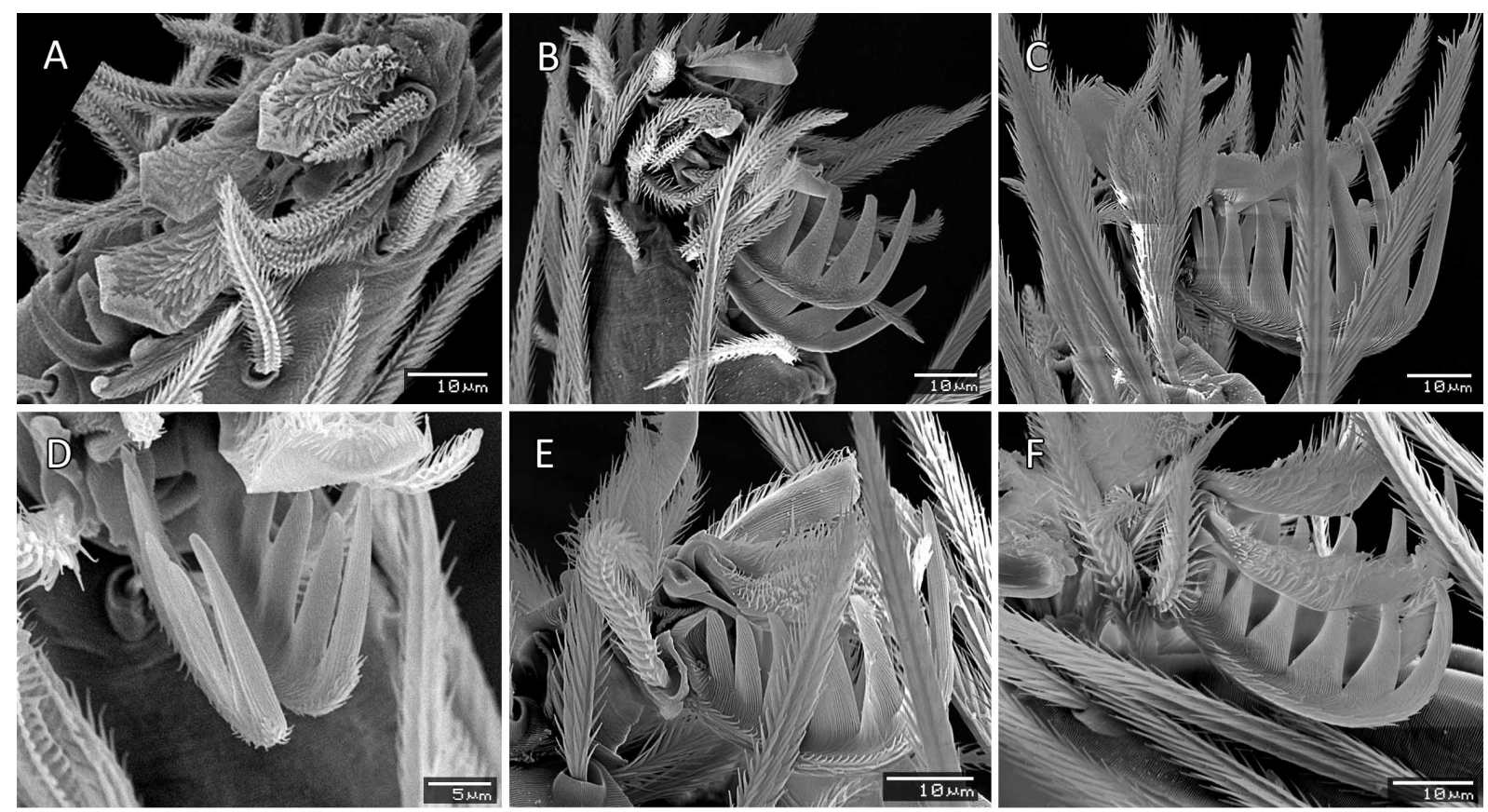

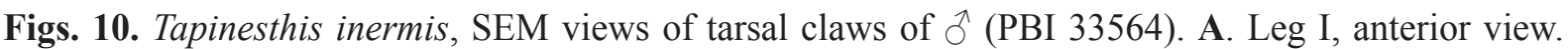
B. Same, lateral view. C. Leg II, lateral view. D. Same, anterior view. E. Leg III, lateral view. F. Leg IV, lateral view. 


\section{Female genitalia}

It is now well established that the internal genital structures of some haplogynes are highly diverse and can be remarkably complex (Uhl 2000; Huber 2002; Burger et al. 2003, 2006; Burger 2007). According to some authors, the complexity of the female genital organ may be correlated to its function for postcopulatory female choice (Burger et al. 2003; Burger 2011a, 2011b, 2011c).

The female genitalia of Tapinesthis inermis are characterized by the presence of a large T-shaped anterior sclerite (AS) based antero-ventrally to the anterior receptaculum (ARe), associated with gland ducts dorsally and apically to the ARe, strong, flattened apodemes and a large, egg-shaped membranous posterior receptaculum.
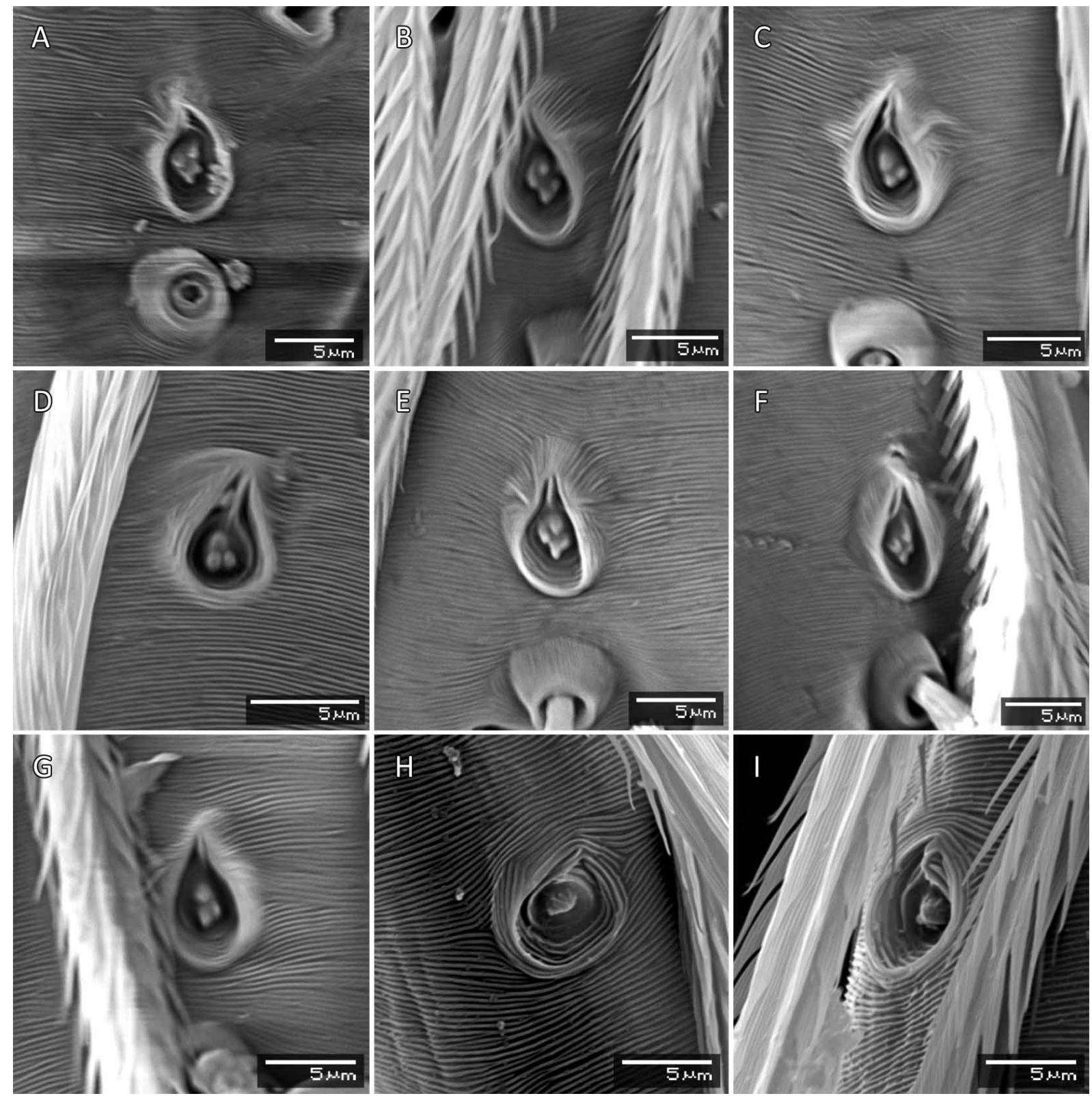

Fig. 11. Tapinesthis inermis, SEM, A-H dorsal views, I lateral view. - A-D. §̊ (PBI 33882). A. Leg I. B. Leg II. C. Leg III. D. Leg IV. - E-G. o (PBI 33883). E. Leg I. F. Leg II. G. Leg III. - H-I. §̋ (PBI 33564). H. Leg IV. I. Tarsal organ, leg IV. 
The combination of these structures is very similar to the one encountered in many dysderoid spiders such as Dysderidae (Forster \& Platnick 1985; Ulh 2000; Burger \& Kropf 2007), Segestriidae (Brignoli 1976), Orsolobidae (Forster \& Platnick 1985; Izquierdo \& Labarque 2010) and some basal Oonopidae such as Puan chechehet Izquierdo, 2012 (Izquierdo et al. 2012) and Unicorn catleyi Platnick \& Brescovit, 1995 (Izquierdo \& Rubio 2011). It thus supports the basal placement of Tapinesthis among Oonopinae.

Burger's terminology for receptacula is based on sections. If a sclerite anterior of the uterus didn't contain sperm in one of the different females analyzed, the use of the term "receptaculum" was considered ambiguous and the term "anterior sclerite" was preferred over "anterior receptaculum". Burger (2010, 2011a, 2013) assumes that in "higher" oonopids, the receptacula are reduced to sclerites and that sperm is stored only in the uterus in order to improve the control over fertilization processes through cryptic female choice (Burger et al. 2003; Burger 2011a, 2011b, 2011c).

In the present work, no sections were made to verify the presence of sperm in those sclerites. However, the use of "ARe" for this sclerite was preferred to differentiate the upper part, i.e., the T-shaped structure

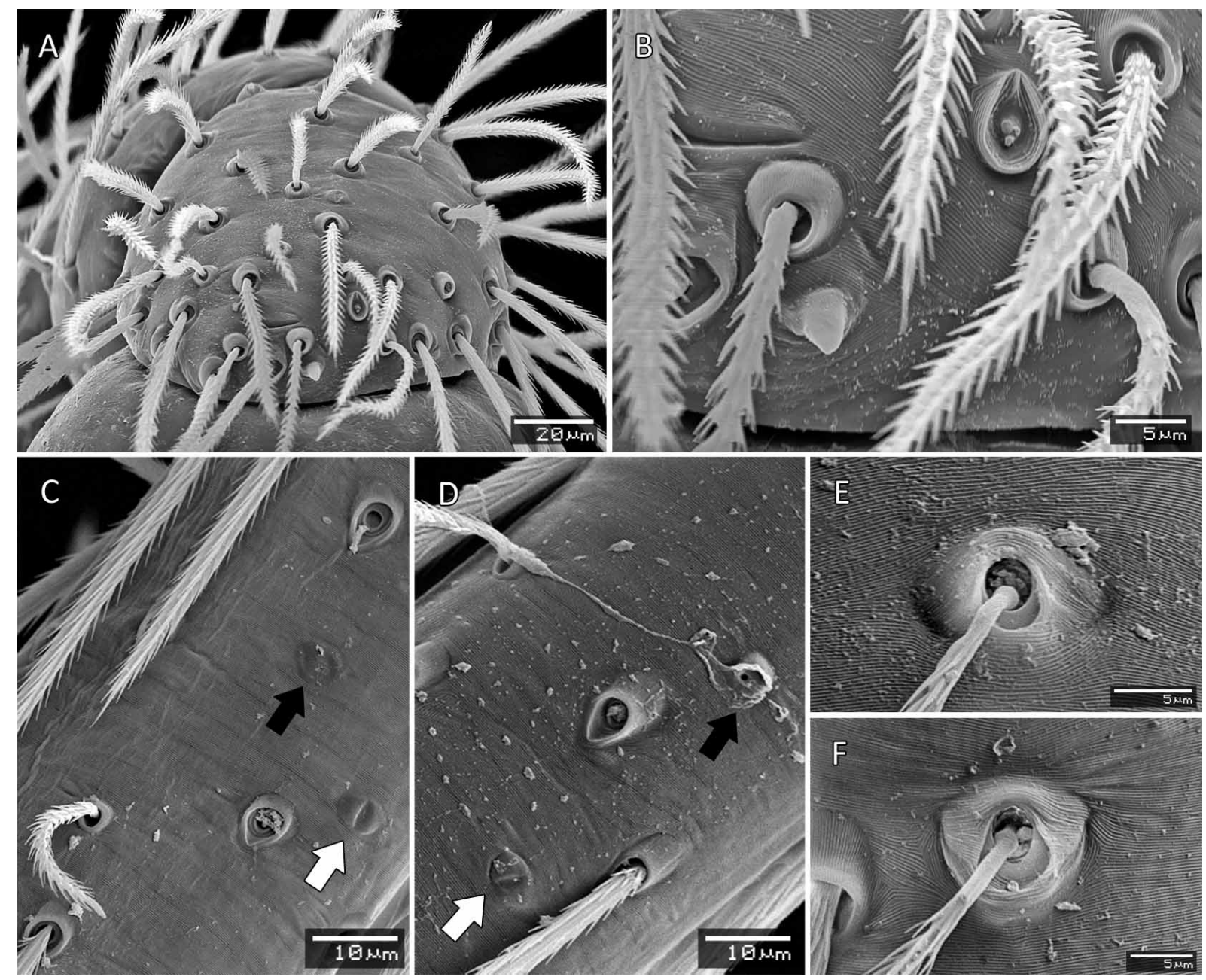

Fig. 12. Tapinesthis inermis d (PBI 33564), SEM views. A. Cymbium, frontal view. B. Same. C. Metatarsus II, dorsal view, black arrow showing pore and white arrow indicating eye-shaped structure. D. Metatarsus IV, black arrow as in C. E. Trichobothrium, dorsal view of bothrium on tibia IV. F. Dorsal view of bothrium on metatarsus. 
called here anterior sclerite (As), which has a different function (muscle attachment, see Izquierdo \& Rubio 2011).

It was not possible to observe the uterus externus (UE). The tissue of that organ typically appears as a very flat, membranous structure on SEMs and the opening for the UE is supposed to be somewhere between the ARe and the PRe (M. Burger, pers. comm.). Again, cross sections are needed to certify the position of the UE. We therefore avoid the term 'Anterior Uterine Sclerite (AUS)' used by Fannes (2010) and Henrard \& Jocqué (2012) for what is called here the AS (e.g.). The term 'uterine' can indeed be confusing, especially since we do not know the position of the uterus on SEMs.

In Tapinesthis, gland ducts are confined to a frontal groove on the apical part of the ARe. In other oonopids, GD are located in the middle of the AS (e.g., Puan chechehet, see Izquierdo et al. 2012) or at the base of the AS (e.g., Heteroonops spinimanus, see Burger 2011a; Oonopinus kilikus, see Burger 2013). Note that GD are also present on the AS in other dysderoid genera of the families Orsolobidae (Izquierdo \& Labarque 2010), Segestriidae (Brignoli 1976; Forster \& Platnick 1985) and Dysderidae (Uhl 2000). According to Burger (2011b), gland ducts associated with the anterior sclerites may produce part of the secretion surrounding the spermatozoa in the posterior receptacula. This secretion may either serve to store and fix the spermatozoa within the receptaculum or provide nutrition for the spermatozoa (e.g., Uhl 1994, 1996).

\section{Relationships}

Simon (1893) recognized two informal groups, 'molles' and 'loricatae', based on the presence of abdominal scuta and sclerotization of the body. Petrunkevitch (1923) and subsequent authors recognized these groups as subfamilies, Oonopinae and Gamasomorphinae, respectively. Later, a third subfamily, the monotypic Orchestininae, was added for the genus Orchestina (Chamberlin \& Ivie 1942). In a recent paper, Platnick et al. (2012) profoundly changed the subfamilial structure of the Oonopidae. The main characters they used were the structure of the tarsal organs and more precisely their number of receptors, the sclerotization of the spermduct in the male palp and the position of the eyes. On the basis of seven characters, the family was subdivided into three subfamilies: the Sulsulinae, Oonopinae and Orchestininae, which remained monotypic.

The three main characters on which the recent subfamilial structure is based are not straightforward in all the oonopids and may need an additional state. In Tapinesthis, and a few other genera, it might indeed be questioned whether the eyes are clumped and whether the male palpal bulbus lacks a sclerotized sperm duct. The situation in Tapinesthis can be considered as intermediate between Orchestininae and Oonopinae: the eyes are not really clumped but also not as far apart as in Orchestina and they nearly have an H-shaped disposition with a slightly recurved PER. The absence of a clearly thick-walled, heavily sclerotized sperm duct within the male palp leaves no doubt about the placement of Tapinesthis among Oonopinae. The sperm duct in the bulbus of Tapinesthis has a thin-walled part, but the distal part is still clearly sclerotized. However, this structure cannot be considered identical to the sclerotized duct as found in Orchestina and the outgroups used in Platnick et al. (2012); hence an intermediate state for this set-up would be necessary. The tarsal organ receptor pattern that gives the impression to be 4433 at a first glance turns out to be 3322, since the distalmost receptor appears to be bifid. Here again, this configuration would best be considered as a separate state different from both the "simple" 3322 without a bifid receptor and the plesiomorphic 4433 receptor formulas.

In view of these modifications, a more extensive set of characters will be needed to clarify the position of Tapinesthis within the Oonopinae. However, the combination of the characters discussed above supports a relatively basal placement of Tapinesthis in the Oonopinae. In addition, recent molecular results of De 
Busschere et al. (submitted), which place Tapinesthis relatively basally among the Oonopinae, appear to corroborate our findings on the basis of morphology.

\section{Acknowledgements}

The present study is part of a Planetary Biodiversity Inventory (PBI) project of the family Oonopidae, coordinated by the American Museum of Natural History (AMNH), New York. We are indebted to Jørgen Lissner for the loan of material (Tapinesthis inermis ${ }^{\lambda}$ from the Czech Republic). We thank Y. Marusik for sharing the nice picture of the $\delta$ palp (Fig. 4E). M. Burger and M. Izquierdo shared their knowledge of the Oonopidae in order to solve difficulties with the interpretation of the structure of the female genitalia. B. Huber, P. Michalik and M. Ramirez commented on the structure in the cleared male palp. This paper is publication BRC 307 of the Biodiversity Research Center (Université Catholique de Louvain).

\section{References}

Brignoli P.M. 1976. Ragni d'Italia XXIV. Note sulla morfologia dei genitali interni dei Segestriidae e cenni sulle specie italiane (Araneae). Fragmenta Entomologica 12: 19-62.

Burger M. 2009. Female genitalia of goblin spiders (Arachnida: Araneae: Oonopidae): a morphological study with functional implications. Invertebrate Biology 128: 340-358. http://dx.doi.org/10.1111/j.17447410.2009.00181.x

Burger M. 2010. Goblin spiders without distinct receptacula seminis (Arachnida: Araneae: Oonopidae). Journal of Morphology 271: 1110-1118. http://dx.doi.org/10.1002/jmor.10857

Burger M. 2011a. Structure and function of the female reproductive system in three species of goblin spiders (Arachnida: Araneae: Oonopidae). Invertebrate Biology 130: 148-160.

Burger M. 2011b. Functional morphology of female goblin spider genitalia (Arachnida: Araneae: Oonopidae) with notes on fertilization in spiders. Zoologischer Anzeiger 250: 123-133. http://dx.doi. org/10.1016/j.jcz.2010.12.003

Burger M. 2011c. Structure and function of the female reproductive system in three species of goblin spiders (Arachnida: Araneae: Oonopidae). Invertebrate Biology 130: 148-160. http://dx.doi.org/10.1111/ j.1744-7410.2011.00227.x

Burger M. 2013. Genital morphology of female goblin spiders (Arachnida: Araneae: Oonopidae) with functional implications. Acta Zoologica (Stockholm) 92: 280-290. http://dx.doi.org/10.1111/j.14636395.2011.00553.x

Burger M., Graber W., Michalik P. \& Kropf C. 2006. Silhouettella loricatula (Arachnida, Araneae, Oonopidae) a haplogyne spider with complex female genitalia. Journal of Morphology 258: 663-677. http://dx.doi.org/10.1002/jmor.10435

Burger M., Izquierdo M. \& Carrera P. 2010. Female genital morphology and mating behaviour of Orchestina (Arachnida: Araneae: Oonopidae). Zoology 113: 100-109. http://dx.doi.org/10.1016/j. zool.2009.08.001

Burger M. \& Kropf C. 2007. Genital morphology of the haplogyne spider Harpactea lepida (Arachnida, Araneae, Dysderidae). Zoomorphology 126: 45-52. http://dx.doi.org/10.1007/s00435-007-0029-1

Burger M. \& Michalik P. 2010. The male genital system of goblin spiders: evidence for the monophyly of Oonopidae (Arachnida: Araneae). American Museum Novitates 3675: 1-13. http://dx.doi. org/10.1206/654.1 
Burger M., Nentwig W. \& Kropf C. 2003. Complex genital structures indicate cryptic female choice in a haplogyne spider (Arachnida, Araneae, Oonopidae, Gamasomorphinae). Journal of Morphology 255: 80-93. http://dx.doi.org/10.1002/jmor.10048

Dalmas R. de 1916. Révision du genre Orchestina E.S., suive de la description de nouvelles espèces du genre Oonops et d'une étude sur les Dictynidae du genre Scotolathys. Annales de la Société entomologique de France 85: 203-258.

Dalmas R. de. 1920. Captures d'araignées rares dans la région parisienne. Bulletin de la Société entomologique de France 1920: 59-60.

Emerton J.H. 1909. Supplement to the New England spiders. Transactions of the Connecticut Academy of Arts and Sciences 14: 171-236.

Forster R.R. \& Platnick N.I. 1985. A review of the austral spider family Orsolobidae (Arachnida, Araneae), with notes on the superfamily Dysderoidea. Bulletin of the American Museum of Natural History 181: 1-230.

Grismado C.J. 2010. Description of Birabenella, a new genus of goblin spiders from Argentina and Chile (Araneae: Oonopidae). American Museum Novitates 3693: 1-21. http://dx.doi.org/10.1206/3693.2

Grismado C.J., Deeleman C., Piacentini L., Izquierdo M.A. \& Ramírez M.J. In press. A taxonomic review of the goblin spiders of the genus Dysderoides Fage and their Himalayan relatives of the genera Trilacuna Tong \& Li, and Himalayana new genus (Araneae: Oonopidae). Bulletin of the American Museum of Natural History.

Grismado C.J. \& Ramírez M.J. 2013. The New World goblin spiders of the new genus Neotrops (Araneae, Oonopidae). Part 1. Bulletin of the American Museum of Natural History 383: 1-150.

Henrard A. \& Jocqué R. 2012. An overview of Afrotropical canopy-dwelling Orchestina (Araneae, Oonopidae), with a wealth of remarkable sexual dimorphic characters. Zootaxa 3284: 1-104.

Heimer S. \& Nentwig W. 1991. Spinnen Mitteleuropas: Ein Bestimmungsbuch. Verlag Paul Parey, Berlin.

Huber B.A. 2004. Evolutionary transformation from muscular to hydraulic movements in spider (Arachnida, Araneae) genitalia: a study based on histological serial sections. Journal of Morphology 261: 364-376. http://dx.doi.org/10.1002/jmor.10255

Izquierdo M.A. \& Labarque F.M. 2010. Description of the female of Orsolobus pucara Forster \& Platnick 1985, with comments on the functional morphology of the female genitalia in Dysderoidea (Araneae: Dysderoidea: Orsolobidae). Journal of Arachnology 38: 511-520.

Izquierdo M.A., Ferretti N. \& Pompozzi G. 2012. On Puan, a new genus of goblin spiders from Argentina (Araneae, Dysderoidea, Oonopidae). American Museum Novitates 3757: 1-22. http://dx.doi. org/10.1206/3757.2

Izquierdo M.A. \& Rubio G.D. 2011. Male genital mutilation in the high-mountain goblin spider, Unicorn catleyi. Journal of Insect Science 118 (11): 1-8. http://dx.doi.org/10.1673/031.011.11801

Kaston B.J. 1948. Spiders of Connecticut. Bulletin - State Geological and Natural History Survey of Connecticut 70: 1-874.

Knoflach B., Pfaller K. \& Stauder F. 2010. Cortestina thaleri - a new dwarf six-eyed spider from Austria and Italy (Araneae: Oonopidae: Oonopinae). Contributions to Natural History 12: 743-771.

Korenko S., Rezác M. \& Pekár S. 2007. Spiders (Araneae) of the family Oonopidae in the Czech Republic. Arachnologische. Mitteilungen 34: 6-8. 
Kraus O. 1967. Zur Spinnenfauna Deutschlands, I. Tapinesthis inermis, eine für Deutschland neue Oonopide (Arachnida: Araneae: Oonopidae). Senckenbergiana Biologica 48: 381-385.

Le Peru B. 2007. Catalogue et répartition des araignées de France. Revue Arachnologique 16: 1-468.

Le Peru B. 2011. The spiders of Europe. Synthesis of data - Volume 1. Atypidae to Theridiidae. Mémoires de la Société Linnéenne de Lyon 2: 1-522.

Lazarov S., Deltshev C. \& Blagoev G. 2001. The spiders (Araneae) of Sashtinska Sredna Gora Mountain (Bulgaria). Faunistic and zoogeographical analysis. Acta Zoologica Bulgarica 53: 3-28.

Petrunkevitch A.I. 1923. On families of spiders. Annals of the New York Academy of Sciences 29: 145180.

Platnick N.I., Abrahim N., Alvarez-Padilla F., Andriamalala D., Baehr B., Baert L., Bonaldo A.B., Brescovit A.D., Chousou-Polydouri N., Dupérré N., Eichenberger B., Fannes W., Gaublomme E., Gillespie R.G., Grismado C.J., Griswold C.E., Harvey M.S., Henrard A., Hormiga G., Izquierdo M.A., Jocqué R., Kranz-Baltensperger Y., Kropf C., Ott R., Ramírez M.J., Raven R.J., Rheims C.A., Ruiz G.R.S., Santos A.J., Saucedo A., Sierwald P., Szuts T., Ubick D. \& Wang X.P. 2012. Tarsal organ morphology and the phylogeny of goblin spiders (Araneae, Oonopidae), with notes on basal genera. American Museum Novitates 3736: 1-52. http://dx.doi.org/10.1206/3736.2

Platnick N.I. 2013. The World Spider Catalog, version 14.5. American Museum of Natural History. http://dx.doi.org/10.5531/db.iz.0001

Platnick N.I. \& Dupérré N. 2010. The goblin spider genera Stenoonops and Australoonops (Araneae, Oonopidae), with notes on related taxa. Bulletin of the American Museum of Natural History 340: 1-111. http://dx.doi.org/10.1206/714.1

Saaristo M.I. \& Marusik Y.M. 2009. A new genus and species of oonopid spider (Araneae, Oonopidae) from Ukraine. ZooKeys 24: 63-74. http://dx.doi.org/10.3897/zookeys.24.278

Simon E. 1882. Etudes arachnologiques. $13^{\mathrm{e}}$ mémoire. XX. Descriptions d'espèces et de genres nouveaux de la famille des Dysderidae. Annales de le Société entomologique de France, Série 6, 2: 201-240.

Simon E. 1893. Histoire Naturelle des Araignées. Vol. 1, part 2. Paris, pp. 257-488.

Simon E. 1914. Les arachnides de France. Synopsis Générale et Catalogue des Espèces Françaises de l'Ordre des Araneae, Paris, 6 (1): 1-308.

Trotta A. 2005. Introduzione al ragni italiani (Arachnida Araneae). Memorie della Società Entomologica Italiana 83: 3-178.

Uhl G. 1994. Genital morphology and sperm storage in Pholcus phalangioides (Fuesslin, 1775) (Pholcidae; Araneae). Acta Zoologica (Stockholm) 75: 1-12. http://dx.doi.org/10.1111/j.1463-6395.1994.tb00957.x

Uhl G. 1996. Sperm storage secretion of female cellar spiders (Pholcus phalangioides; Araneae): A gelelectrophoretic analysis. Journal of Zoology 240: 153-161. http://dx.doi.org/10.1111/j.1469-7998.1996. $\underline{\text { tb05492.x }}$

Uhl G. 2000. Two distinctly different sperm storage organs in female Dysdera erythrina (Araneae: Dysderidae). Arthropod Structure \& Development 29: 163-169. http://dx.doi.org/10.1016/S1467$\underline{8039(00) 00019-0}$

Van Keer K., De Koninck H., Vanuytven H. \& Van Keer J. 2006. Some - mostly southern European spider species (Araneae), new or rare to the Belgian fauna, found in the city of Antwerp. Nieuwsbrief van de Belgische Arachnologische Vereniging 21: 33-40. 
Van Keer K., Vanuytven H., De Koninck H. \& Van Keer J. 2010. More than one third of the Belgian spider fauna (Araneae) found within the city of Antwerp: faunistics and some reflections on urban ecology. Nieuwsbrief van de Belgische Arachnologische Vereniging 25: 160-180.

Manuscript received: 19 December 2013

Manuscript accepted: 18 March 2014

Published on: 5 May 2014

Topic editor: Koen Martens

Desk editor: Danny Eibye-Jacobsen

Printed versions of all papers are also deposited in the libraries of the institutes that are members of the EJT consortium: Muséum National d'Histoire Naturelle, Paris, France; Botanic Garden Meise, Belgium; Royal Museum for Central Africa, Tervuren, Belgium; National History Museum, London, United Kingdom; Royal Belgian Institute of Natural Sciences, Brussels, Belgium; Natural History Museum of Denmark, Copenhagen, Denmark. 